\title{
FAKTOR KEPUASAN WISATAWAN PENGGUNA TRANSPORTASI LAUT DARI BALI KE GILI TRAWANGAN
}

\author{
Syukriyan Abrar Syah ${ }^{1}$, Ni Gusti Ayu Susrami Dewi², Putu Agus Wikanatha Sagita ${ }^{3}$ \\ ${ }^{1}$ Email : shinokami.riyan@gmail.com \\ Program Studi S1 Industri Perjalanan Wisata, Fakultas Pariwisata, Universitas Udayana \\ 22Email : susrami_ipw@unud.ac.id \\ Program Studi S1 Industri Perjalanan Wisata, Fakultas Pariwisata, Universitas Udayana \\ 33Email : aguswika@unud.ac.id \\ Program Studi S1 Industri Perjalanan Wisata, Fakultas Pariwisata, Universitas Udayana
}

\begin{abstract}
This research aims to analyze factors affecting the satisfaction of tourists in the use of marine transportation from Bali toward Gili Trawangan. The benefits of this research useful to the company in improving the services for tourists who will use the services of a crosswalk leading to Gili Trawangan. The respondents in this research totalled 190 respondents, the selection of the sample using the method of purposive sampling, the data in this study were analyzed using the analysis factors that help by statistikal program SPSS version 17.0 for windows. The results of this study are: 1) the satisfaction of tourists in the use of sea transport in general are at a level of satisfaction. 2) there are three factors that affect the satisfaction of tourists formed i.e. factors quality of maids, the cost factor $\&$ ease factors and product quality. Quality of service factor is the most dominant factor influencing the satisfaction of travellers with variable reliability as the dominant variables, and the variable availability schedule is a variable that must be improved.
\end{abstract}

Abstrak: Penelitian ini bertujuan untuk menganalisis faktor-faktor yang mempengaruhi kepuasan wisatawan dalam penggunaan transportasi laut dari Bali menuju Gili Trawangan. Manfaat dari penelitian ini berguna untuk perusahaan dalam meningkatkan pelayanan bagi wisatawan yang akan menggunakan jasa penyeberangan menuju Gili Trawangan. Responden dalam penelitian ini berjumlah 190 responden, pemilihan sampel menggunakan metode purposive sampling, data dalam penelitian dianalisis menggunakan analisis faktor yang di bantu oleh program statistikal SPSS version 17.0 for windows. Hasil penelitian ini adalah: 1) kepuasan wisatawan dalam penggunaan transportasi laut secara umum berada pada tingkat puas menurut skala interval kepuasan dengan 19 variabel yang dinilai. 2) terdapat 3 faktor terbentuk yang mempengaruhi kepuasan wisatawan yaitu faktor kualitas pelayan dengan eigenvalue sebesar 6.670, faktor biaya \& kemudahan dengan eigenvalue sebesar 1.747 dan faktor kualitas produk dengan eigenvalue sebesar 1.465. Faktor kualitas pelayanan merupakan faktor yang paling dominan mempengaruhi kepuasan wisatawan dengan variabel keandalan sebagai variabel paling dominan, dan variabel ketersediaan jadwal adalah variabel yang harus ditingkatkan.

Keywords: The satisfaction of tourists, marine transportation, Gili Trawangan. 


\section{PENDAHULUAN}

Pariwisata merupakan salah satu fenomena yang selalu dikaitkan dengan kegiatan perjalanan seseorang untuk memperoleh pengalaman baru yang menyenangkan dan berkesan. Pariwisata dianggap sebagai suatu aset yang strategis untuk mendorong pembangunan pada wilayahwilayah tertentu yang mempunyai potensi objek wisata sehingga dapat membawa manfaat dan pengaruh yang cukup besar meliputi aspek ekonomi (sumber devisa), aspek sosial (penciptaan lapangan kerja) dan aspek budaya. Salah satu pariwisata yang terkemuka di dunia adalah pulau Bali, hal ini dikemukakan oleh Tempo.co (2018) menyatakan "meraih posisi baik pada destinasi wisata dari 25 destinasi terbaik di seluruh dunia menurut TripAdvisor. Menurut Medlik, (1980) (dalam Ariyanto 2005), ada empat aspek (4A) yang harus diperhatikan dalam penawaran pariwisata adalah daya tarik (attraction), transportasi (accessibility), fasilitas (amenities) dan kelembagaan (ancillary). Salah satu penunjang terpenting adalah aksesibilitas yang merupakan fungsi utama transportasi, dan transportasi merupakan sarana memindahkan wisatawan dari satu tempat ketempat yang lainnya, guna memudahkan wiatawan dalam tujuan berwisata. Bali mempunyai beberapa transportasi seperti, transportasi darat dan transportasi laut. Transportasi laut yang sering atau banyak diminati wisatawan adalah kapal cepat/speed boat dengan tujuan Gili Trawangan. Hal ini juga dikemukakan oleh Bupati Lombok Utara Provinsi NTB (Nusa Tenggra Barat) dalam kompas.com (2017) menyatakan bahwa wisatawan yang datang ini melalui Lombok International Airport (LIA) dan menggunakan kapal cepat (fast boat) dari Bali. Hal ini juga dinyatakan bahwa peningkatan jumlah kunjungan ke gili trawangan sangat berkembang dikarenakan berkat beroperasinya 20 -an kapal cepat yang mengangkut wisatawan dari Bali.

Peningkatan jumlah wisatawan yang berkunjung ke Gili menyebabkan semakin banyaknya jumlah perusahaan jasa transportasi laut yang berdampak pada semakin ketat persaingan diantara perusahaan sejenis, masing - masing perusahaan bertujuan untuk mendapatkan pembelian ulang dengan menyediakan berbagai macam model standar kepuasan untuk pengguna jasa transportasi laut, dikarenakan tidak semua perusahaan telah memiliki standar bagi kepuasan wisatawan yang menggunakan transportasi laut dari Bali menuju Gili Trawangan. Dalam penggunaan sebuah trasnportasi wisatawan juga mendapatkan jasa pelayanan yang diberikan oleh sebuah perusahaan untuk memenuhi kebutuhan akan transportasi. hal ini dapat mempengaruhi sebuah rasa senang, dan terpenuhinya harapan wisatawan, dimana juga dapat berpengaruh terhadap kepuasan wisatawan sebagai konsumen yang menggunakan jasa transportasi laut pada sebuah perusahaan tertentu.

Kepuasan konsumen adalah tingkat perasaan konsumen setelah membandingkan antara apa yang dia terima dan harapannya (Umar 2005). Seorang pelanggan, jika merasa puas dengan nilai yang diberikan oleh produk atau jasa, sangat besar kemungkinannya menjadi pelanggan dalam waktu yang lama. Dalam hal ini kualitas perusahaan sangat penting baik itu dari segi pelayanan, fasilitas, dan produk yang di tawarkan oleh perusahaan tersebut. Kepuasan adalah hal penentu loyalitas dari konsumen untuk tetap bertahan di satu perusahaan. Di dalam meningkatkan kepuasan konsumen terdapat faktor-faktor yang mempengaruhi kepuasan wisatawan.

Faktor-faktor yang mempengaruhi kepuasan konsumen menurut Zeithmal dan Bitner (2003) mengemukakan bahwa kepuasan adalah konsep yang jauh lebih luas dari hanya sekedar penilaian kualitas pelayanan, namun juga dipengaruhi oleh faktor-faktor lain yang dapat dijelaskan sebagai berikut: kualitas pelayanan, kualitas produk, harga, faktor situasi, dan faktor pribadi dari konsumen. Perusahaan transportasi harus mementingkan juga kepuasan wisatawan. Dengan semakin beragamnya perusahaan transportasi laut yang menawarkan jasa penyeberangan dari Bali menuju Gili Trawangan, maka akan semakin ketat persaingan masing-masing perusahaan, dan faktor-faktor yang mempengaruhi kepuasan wisatawan akan sangat penting untuk diteliti.

Perkembangan wisatawan yang menggunakan transportasi laut sejak tahun 2012 yang lalu menuju Gili Trawangan membuat semakin beragamnya perusahaan transportasi laut yang menawarkan jasa penyeberangan dari Bali menuju Gili Trawangan. Semakin beragamnya perusahaan yang menyediakan jasa penyeberangan maka 
semakin ketat persaingan di antara perusahaan tersebut aksn memberikan kepuasan wisatawan pengguna transportasi yang berujung pada pembelian ulang dan loyalitas wisatawan pengguna transportasi dan faktorfaktor yang mempengaruhi kepuasan wisatawan akan sangat penting untuk diteliti. Faktor-faktor yang mempengaruhi kepuasan wisatawan lebih berfokus pada bagaimana pelayanan yang diberikan oleh masing-masing perusahaan terhadap wisatawan pengguna transportasi laut dari Bali ke Gili Trawangan, dimana hal tersebut berdampak baik untuk perusahaan yang mendapatkan kepuasan wisatawan yang menggunakan jasa penyeberangan masing-masing perusahaan.

Mengangkat judul Analisis Faktor Kepuasan Wisatawan Pengguna Transportasi Laut Dari Bali Ke Gili Trawangan diharapkan mampu memberikan kontribusi pada pihak swasta (pemilik perusahaan transportasi laut) sehingga dapat mengutamakan kepuasan yang optimal bagi wisatawan. Penelitian ini bertujuan untuk perusahaan yang menyediakan jasa penyeberangan agar dapat memperhatikan keinginan dan kebutuhan wisatawan sesuai standar kepuasannya dengan faktor apa saja yang mempengaruhi kepuasan wisatawan dalam penggunaan transportasi laut dari Bali menuju Gili Trawangan dan faktor dominannya.

\section{METODE PENELITIAN}

Penelitian ini dilakukan di Gili Trawangan yang terletak di Desa Gili Indah, Kecamatan Pemenang, Kabupaten Lombok Utara, Provinsi Nusa Tenggara Barat. Variabel pertama yang digunakan adalah karakteristik wisatawan yang dialamnya terdapat dua sub variabel yaitu trip descriptor batasan dalam sub variabel ini adalah jarak yang ditempuh, jenis akomodasi yang digunakan, pengorganisasian perjalanan, dan besar pengeluaran. Sedangkan tourist descriptor dibedakan menjadi dua sosio-demografis dan geografis. Variabel kedua yang digunakan untuk mengukur kepuasan wisatawan pengguna transportasi laut dari Bali menuju Gili Trawangan adalah kualitas jasa berupa technical quality yaitu harga, ketepatan waktu, kecepatan, functional quality yaitu cara penyampaian jasa, dan corporate image yaitu reputasi perusahaan. Variabel ketiga yang digunakan untuk mengukur faktor kepuasan wisatawan pengguna transportasi laut dari Bali menuju Gili Trawangan adalah kualitas pelayanan berupa reliability, responsiveness, competence, access, courtesy, communication, credibility, security, understanding the costumer, dan tangibles.

Teknik pengumpulan data dilakukan dengan observasi, kuesioner, wawancara, studi kepustakaan, dan dokumentasi. Teknik penentuan sampel dilakukan dengan purposive sampling, pengumpulan data dilakukan dengan penyebaran kuesioner terhadap 190 responden. Teknik Analisis data dilakukan dengan uji validitas, uji reliabilitas, dan analisis faktor.

Analisis faktor adalah kajian tentang saling ketergantungan antara variabel-variabel, dengan tujuan untuk menemukan himpunan variabel-variabel baru, yang lebih sedikit jumlahnya dari pada variabel semula, dan yang menunjukkan yang mana di antara variabelvariabel semula tersebut yang merupakan faktor-faktor persekutuan (Suryanto, 1988). Jenis analisis faktor yang digunakan dalam penelitian ini adalah ekploratoris karena jumlah faktor serta variabel mana saja yang terkait dengan faktor tertentu secara apriori belum ada atau tidak diketahui.

\section{HASIL DAN PEMBAHASAN}

Gili Trawangan terletak di Desa Gili Indah, Kecamatan Pemenang, Kabupaten Lombok Utara, Provinsi Nusa Tenggara Barat. Gili Trawangan terletak dalam Kawasan Taman Wisata Alam Laut Gili Indah yang mempunyai total luas 2.954 hektar. Luas daratan Gili Trawangan 340 hektar dengan keliling pulau 7,5 kilometer dan selebihnya merupakan perairan laut. Jumlah penduduk Gili Trawangan sebanyak 1517 jiwa. Secara geografis Gili Trawangan terletak pada bagian Barat Lombok.

Berdasarkan hasil penelitian melalui kuisioner yang disebarkan secara menyeluruh maka dapat diketahui gambaran karakteristik wisatawan yang menggunakan transportasi laut dari Bali menuju Gili Trawangan berdasarkan kewarganegaraan wisatawan di dominasi oleh wisatawan berkewarganegaraan Perancis sebesar 26.84\%. Berdasarkan umur wisatawan yang paling banyak berumur 28-37 tahun sebesar $42.11 \%$. Berdasarkan pekerjaan wisatawan yang paling banyak adalah pegawai swasta sebesar $48.42 \%$. Berdasarkan jenis kelamin wisatawan hampir sebanding yaitu 
sebesar 51.58\% untuk jenis kelamin perempuan dan $48.42 \%$ untuk jenis kelamin laki-laki. Berdasarkan status perkawinan terbesar adalah single sebesar 51.58\%. Berdasarkan pendidikan terakhir wisatawan yang menggunakan transportasi laut dari Bali menuju Gili Trawangan di dominasi oleh pendidikan terakhir sarjana sederajat yaitu sebesar $68.95 \%$. Berdasarkan tempat keberangkatan wisatawan yang digunakan wisatawan dari Bali menuju Gili Trawangan paling banyak berangkat dari Padang Bai yaitu sebesar $35.79 \%$ dan paling sedikit dari Sanur yaitu sebesar $8.95 \%$. Berdasarkan pengorganisasian perjalanan mereka didominasi oleh pengorganisasian sendiri yaitu sebesar 93.68\%. Berdasarkan motivasi Perjalanan wisatawan yang menggunakan transportasi laut dari Bali menuju Gili Trawangan didominasi oleh motivasi beriwisata karena ingin melakukan recreation/sport sebesar $61.05 \%$. Berdasarkan lama tinggal wisatawan yang menginap di Gili Trawangan paling banyak sebesar $48.42 \%$ (4 7 hari) dan paling sedikit $7.37 \%$ (12 - 15 hari). Berdasarkan harga tiket yang didapatkan oleh wisatawan pengguna transportasi laut dari Bali menuju Gili Trawangan berbeda - beda tergantung bagaimana cara wisatawan mendapatkan tiket dan perusahaan apa yang digunakan oleh wisatawan, wisatawan mendapatkan harga tiket paling banyak \$76 $\$ 100$ sebesar $35.79 \%$, setelahnya $\$ 101$ - \$125 sebesar 33.16\%. Cara wisatawan mendapatkan tiket paling banyak yaitu dari perusahaan transportasi laut sebesar 34.74\%, Travel Agent $24.21 \%$ dan TICs $22.63 \%$. Perusahaan yang digunakan oleh wisatawan pengguna transportasi laut dari Bali menuju Gili Trawangan paling banyak digunakan adalah Patagonia Express sebesar 14.74\%, Blue Water dan Ekajaya Fastboat masing - masing sebesar $12.63 \%$. Ketiga perusahaan tersebut merupakan perusahaan besar yang memiliki kapal dengan kapasitas besar dan tampilan yang mewah. Standar keamanan yang diberikan oleh perusahaan merupakan standar Internasional, maka hasil dari penelitian ini menjadi relevan terkait perusahaan yang digunakan oleh wisatawan.

Berdasarkan hasil penelitian melalui kuisioner yang disebarkan secara menyeluruh maka dapat diketahui gambaran karakteristik wisatawan yang menggunakan transportasi laut dari Bali menuju Gili Trawangan.
Kewarganegaraan wisatawan di dominasi oleh wisatawan berkewarganegaraan Perancis sebesar $26.84 \%$. Hal ini dikarenakan wisatawan berkewarganegaraan banyak berwisata dari Amed berdasarkan hasil kuesioner tempat keberangkatan wisatawan juga menunjang wisatawan berkewarganegaraan Perancis adalah yang terbanyak menggunakan transportasi laut dari Bali menuju Gili Trawangan.

Umur wisatawan yang paling banyak berumur 28-37 tahun sebesar $42.11 \%$. Hal ini dikarenakan wisatawan yang menggunakan transportasi laut dari Bali menuju Gili Trawangan di dominasi oleh umur produktif dan sedang dalam masa mencari sesuatu seperti pengalaman, maka umur produktif yang menjadi paling banyak dalam menggunakan transportasi laut dari Bali menuju Gili Trawangan. Pekerjaan wisatawan yang paling banyak adalah pegawai swasta sebesar 48.42\%. Hal ini dikarenakan wisatawan yang menggunakan transportasi laut dari Bali menuju Gili Trawangan sedang dalam musim liburan, maka pegawai swasta yang paling banyak menggunakan transportasi laut dari Bali menuju Gili Trawangan.

Jenis kelamin wisatawan hampir sebanding yaitu sebesar $51.58 \%$ untuk jenis kelamin perempuan dan $48.42 \%$ untuk jenis kelamin laki-laki. Hal ini dikarenakan wisatawan yang menggunakan transportasi laut dari Bali menuju Gili Trawangan banyak yang berpasang - pasangan ataupun dalam jumlah group atau bersama keluarga, dan bisa dikatakan bahwa wisatawan yang menggunakan transportasi laut dari Bali menuju Gili Trawangan tidak ada yang melakukan perjalanan sendirian. Status perkawinan terbesar adalah single hal ini dikarenakan wisatawan yang menggunakan transportasi laut dari Bali menuju Gili Trawangan banyak yang berpasangan pasangan seperti yang dijelaskan pada paragraf sebelumnya, maka tidak semua pasangan tersebut sudah menikah. Berdasarkan analisa peneliti wisatawan yang berpergian ke Gili Trawangan sebagian besar untuk tujuan berlibur, jadi tidak ada masalah jika wisatawan pergi berlibur dengan siapa saja dan sebagian besar wisatawan lebih memilih pengorganisasian perjalanan sendiri, dimana tidak memerlukan adanya campur tangan biro perjalanan wisata dalam waktu liburan wisatawan. 
Pendidikan terakhir wisatawan yang menggunakan transportasi laut dari Bali menuju Gili Trawangan di dominasi oleh pendidikan terakhir sarjana sederajat yaitu sebesar 68.95\%. Hal ini dikarenakan wisatawan banyak yang berumur produktif dan sudah selesai dalam masa belajar/sekolah, maka banyak wisatawan yang menggunakan transportasi laut dari Bali menuju Gili Trawangan memiliki pendidikan terakhir sarjana sederajat, karena sarjana sederajat merupakan pendidikan terakhir yang standar untuk bisa mendapatkan perkerjaan ditambah banyaknya pekerjaan wisatawan yang menjadi pegawai swasta.

Tempat keberangkatan wisatawan yang digunakan wisatawan dari Bali menuju Gili Trawangan paling banyak berangkat dari Padang Bai yaitu sebesar 35.79\% dan paling sedikit dari Sanur yaitu sebesar $8.95 \%$. Hal ini dikarenakan pelabuhan Padang Bai merupakan pelabuhan yang paling besar di Bali untuk keberangkatan speed boat menuju Gili Trawangan, dimana terdapat 8 perusahaan dari 18 perusahaan speed boat yang ada di Bali untuk keberangkatan khusus menuju Gili Trawangan. Sedangkan Sanur menjadi paling sedikit hal ini dikarenakan pelabuhan speed boat yang ada di Sanur hanya memiliki 1 perusahaan yang menyediakan accessibilities menuju Gili Trawangan.

Pengorganisasian perjalanan mereka didominasi oleh pengorganisasian sendiri yaitu sebesar 93.68\%. Hal ini dikarenakan wisatawan yang berangkat dari Bali menuju ke Gili Trawangan tujuan berlibur mereka adalah untuk berekreasi dan bersantai, wisatawan hanya perlu pihak lain untuk sebagai fasilitator mereka seperti tiket speed boat dan hotel, diluar dari hal tersebut berdasarkan hasil observasi wisatawan melakukan semuanya berdasarkan apa yang mereka ingin dan butuhkan.

Motivasi Perjalanan wisatawan yang menggunakan transportasi laut dari Bali menuju Gili Trawangan didominasi oleh motivasi beriwisata karena ingin melakukan recreation/sport sebesar $61.05 \%$. Hal ini dikarenakan wisatawan yang melakukan perjalanan ke Gili Trawangan hanya untuk menikmati daerah tujuan wisata sebagai wisatawan. Sedangkan yang paling sedikit yaitu motivasi perjalanan untuk status dan prestise sebesar $4.21 \%$, hal ini dikarenakan wisatawan yang menggunakan transportasi laut dari Bali menuju Gili Trawangan tujuan utama mereka adalah liburan (pleasure time).

Lama tinggal wisatawan yang menginap di Gili Trawangan paling banyak sebesar $48.42 \%$ ( $4-7$ hari) dan paling sedikit $7.37 \%$ (12 - 15 hari). Hal ini dikarenakan wisatawan yang berwisata ke Gili Trawangan lebih menikmati berlibur sepekan di Gili Trawangan dan segera melanjutkan perjalanan ke destinasi lain. Harga tiket yang didapatkan oleh wisatawan pengguna transportasi laut dari Bali menuju Gili Trawangan berbeda - beda tergantung bagaimana cara wisatawan mendapatkan tiket dan perusahaan apa yang digunakan oleh wisatawan.

Harga Tiket paling banyak $\$ 76-\$ 100$ sebesar $35.79 \%$, setelahnya $\$ 101-\$ 125$ sebesar $33.16 \%$. Cara wisatawan mendapatkan tiket paling banyak yaitu dari perusahaan transportasi laut sebesar 34.74\%, Travel Agent $24.21 \%$ dan TICs $22.63 \%$. Hal ini dikarenakan wisatawan berbagai macam faktor yang dilakukan oleh masing-masing perusahaan transportasi laut untuk pemasaran mereka, sehingga beragam cara wisatawan mendapatkan tiket menggunakan transportasi laut dari Bali menuju Gili Trawangan yang ditemukan peneliti.

Perusahaan yang digunakan oleh wisatawan pengguna transportasi laut dari Bali menuju Gili Trawangan paling banyak digunakan adalah Patagonia Express sebesar $14.74 \%$, Blue Water dan Ekajaya Fastboat masing - masing sebesar $12.63 \%$. Ketiga perusahaan tersebut merupakan perusahaan besar yang memiliki kapal dengan kapasitas besar dan tampilan yang mewah. Standar keamanan yang diberikan oleh perusahaan merupakan standar Internasional, maka hasil dari penelitian ini menjadi relevan terkait perusahaan yang digunakan oleh wisatawan.

Faktor-faktor awal yang digunakan untuk melihat faktor yang mempengaruhi kepuasan wisatawan dalam menggunakan transportasi laut dari Bali menuju Gili Trawangan yaitu terdiri atas 19 indikator yang ada pada 2 faktor. Hal tersebut didapat dari faktor-faktor penentu kepuasan wisatawan.

Adapun faktor-faktor dan variabel yang dimaksud antara lain dimensi kualitas jasa yang terdiri dari Harga (X1.1), Tepat waktu (X1.2), Kecepatan (X1.3), Penyampaian Jasa (X1.4), Citra dan Reputasi (X1.5). Dimensi kualitas pelayanan yang terdiri dari Keandalan (X2.1), Ketanggapan (X2.2), 
Tanggung Jawab (X2.3), Kemudahan Tiket (X2.4), Kemudahan Informasi (X2.5), Kemudahan Pembayaran (X2.6). Jadwal Bervariasi (X2.7), Keramahan (X2.8), Komunikasi (X2.9), Kepercayaan (X2.10), Keamanan (X2.11), Memahami Pelanggan (X2.12), Tampilan (X2.13), Fasilitas Keselamatan (X2.14).

Berdasarkan sumber yang didapat tersebut, maka ke 2 faktor tersebut dijadikan sebagai variabel dalam penelitian ini dan diuji dengan metode penyebaran kuesioner kepada 190 wisatawan mancanegara atau responden. Hasil dari analisis data menggunakan program SPSS dengan metode analisis faktor. Namun ketika dilakukan uji validitas sebelum dilakukan analisis faktor terhadap 19 indikator tersebut, semua indikator dinyatakan valid karena memenuhi nilai standar uji validitas, maka dari itu untuk analisis faktor semua indikator yang digunakan. Setelah dilakukan uji MSA, dinyatakan bahwa semua indikator valid, karena nilai MSA lebih dari nilai standar.

Adapun hasil yang diperoleh membentuk konsep baru, yang mana menunjukan bahwa dari 2 faktor awal dengan total 19 indikator di atas, maka faktor-faktor yang mempengaruhi kepuasan wisatawan dalam penggunaan transportasi laut dari Bali menuju Gili Trawangan dan menghasilkan tiga faktor terbentuk dengan 18 variabel didalamnya. Faktor yang pertama yaitu kualitas pelayanan, terdiri dari: (1) Keandalan, (2) Tanggung Jawab, (3) Kepercayaan, (4) Ketanggapan, (5) Keamanan, (6) Penyampaian Jasa, (7) Komunikasi, (8) Citra dan Reputasi, (9) Kemudahan Tiket, dan (10) Kemudahan Pembayaran. Faktor kedua yaitu biaya dan kemudahan, terdiri dari: (1) Kecepatan, (2) Kemudahan Informasi, (3) Tepat Waktu, (4) Keramahan, dan (5) Harga. Faktor ketiga yaitu Kualitas Produk, terdiri dari: (1) Memahami Pelanggan, (2) Fasilitas Keselamatan, dan (3) Tampilan. Faktor yang paling dominan yang mempengaruhi kepuasan wisatawan dalam penggunaan transportasi laut dari Bali menuju Gili Trawangan dapat dilihat melalui nilai eigenvalue dalam analisis faktor yaitu sebesar 6.670. Berdasarkan hasil penelitian maka yang menjadi faktor paling dominan yaitu faktor kualitas pelayanan, faktor ini terdiri dari sepuluh indikator pembentuk yaitu: (1) Keandalan, (2) Tanggung Jawab, (3) Kepercayaan, (4) Ketanggapan, (5) Keamanan,
(6) Penyampaian Jasa, (7) Komunikasi, (8) Citra dan Reputasi, (9) Kemudahan Tiket, dan (10) Kemudahan Pembayaran. Faktor kualitas pelayanan, mengungguli faktor lain dengan persentase variance sebesar $35.104 \%$ dan nilai eigenvalue sebesar 6.670.

Faktor kualitas pelayanan merupakan faktor utama yang mempengaruhi kepuasan wisatawan dalam penggunaan transportasi laut dari Bali menuju Gili Trawangan, berhubungan dengan konsep yang diterapkan oleh (Lupyoadi, 2011) dan (Irawan, 2004) bahwa faktor - faktor yang mempengaruhi kepuasan konsumen salah satunya kualitas pelayanan dimana pelanggan akan merasa puas bila mereka mendapatkan pelayanan yang baik atau sesuai dengan yang diharapkan. Hal ini menunjukkan bahwa penciptaan sebuah konsep teori harus berbanding lurus dengan keadaan di lapangan.

Kondisi dilapangan terkait dengan kualitas pelayanan yang diberikan oleh perusahaan transportasi laut sangat baik, sehingga memudahkan wisatawan ketika mendapatkan/membeli tiket penyeberangan. Tidak hanya terkait kemudahan dan tanggung jawab dari kualitas pelayanan yang diberikan oleh perusahaan transportasi laut dari Bali menuju Gili Trawangan, kejelasan informasi yang diberikan oleh pegawai perusahaan transportasi laut sangat jelas seperti fasilitas yang tersedia di kapal dan estimasi waktu perjalanan, banyak dari wisatawan mendengarkan secara teliti bagaimana informasi yang dibutuhkan oleh wisatawan. Kepercayaan wisatawan terhadap perusahaan dapat meminimalisir keragu-raguan wisatawan dalam melakukan penyeberangan dari Bali menuju Gili Trawangan. Hal ini terbukti menurut beberapa informan mengatakan bahwa perusahaan yang mereka gunakan memiliki citra yang baik terkait keselamatan dalam perjalanan dan perusahaan mengandalkan hal tersebut.

Jika ditinjau dari beberapa penelitian mengenai faktor yang mempengaruhi kepuasan wisatawan dalam penggunaan transportasi juga terdapat penelitian tentang kepuasan sebelumnya yang menyebutkan bahwa faktor yang dominan mempengaruhi kepuasan wisatawan yaitu faktor kualitas pelayanan, penelitian ini diperkuat oleh salah satu jurnal oleh Paulalengan (2016) yang menjelaskan bahwa Faktor-Faktor Yang Mempengaruhi Tingkat Kepuasan Wisatawan 
Dalam Penggunaan Maskapai Penerbangan Airasia Di Denpasar yaitu faktor Layanan yang terdiri dari indikator (1) layanan bagasi yang cepat $(0,779)$, (2) layanan tambahan selama terbang (0.757), (3) Harga sebanding dengan fasilitas $(0,679)$, (4) Keandalan petugas groundhandling (0,575),

Keandalan pramugari berbahasa $(0,562)$, (6) Sikap para staff ketika terjadi masalah $(0,517)$.

\section{SIMPULAN DAN SARAN}

\section{Simpulan}

Karakteristik wisatawan yang menggunakan transportasi laut dari Bali menuju Gili Trawangan menurut kewarganegaraan yang paling banyak berkewarganegaraan French sebesar 26.84\%, berumur 26 dan 28 tahun sebesar 8.42\%, bekerja sebagai pegawai swasta sebesar $48.42 \%$, berjenis kelamin perempuan sebesar $51.58 \%$, dengan status perkawinan single sebesar 51.58\%, pendidikan terakhir wisatawan di dominasi oleh pendidikan terakhir sarjana sederajat yaitu sebesar 68.95\%, kebanyakan berangkat dari Padang Bai yaitu sebesar $35.79 \%$, pengorganisasian perjalanan sendiri yaitu sebesar 93.68\%, motivasi perjalanan Recreation/sport sebesar $61.58 \%$, dengan lama Tinggal wisatawan yang paling banyak sebesar $48.42 \%$ ( $4-7$ hari), dan harga Tiket yang dibayar \$76 - \$100 sebesar $35.79 \%$.

Faktor-faktor yang mempengaruhi kepuasan wisatawan dalam penggunaan transportasi laut dari Bali menuju Gili Trawangan menghasilkan tiga faktor terbentuk dengan 18 variabel didalamnya. Antara lain: Faktor yang pertama yaitu kualitas pelayanan, terdiri dari: (1) Keandalan, (2) Tanggung Jawab, (3) Kepercayaan, (4) Ketanggapan, (5) Keamanan, (6) Penyampaian Jasa, (7) Komunikasi, (8) Citra dan Reputasi, (9) Kemudahan Tiket, dan (10) Kemudahan Pembayaran. Faktor kedua yaitu biaya dan kemudahan, terdiri dari: (1) Kecepatan, (2) Kemudahan Informasi, (3) Tepat Waktu, (4) Keramahan, dan (5) Harga. Faktor ketiga yaitu Kualitas Produk, terdiri dari: (1) Memahami Pelanggan, (2) Fasilitas Keselamatan, dan (3) Tampilan.

Faktor dominan yang mempengaruhi kepuasan wisatawan dalam penggunaan transportasi laut dari Bali menuju Gili Trawangan dapat dilihat melalui nilai eigenvalue dalam analisis faktor yaitu sebesar
6.670. Berdasarkan hasil penelitian maka yang menjadi faktor paling dominan yaitu faktor kualitas pelayanan, faktor ini terdiri dari sepuluh indikator pembentuk yaitu: (1) Keandalan, (2) Tanggung Jawab, (3) Kepercayaan, (4) Ketanggapan, (5) Keamanan, (6) Penyampaian Jasa, (7) Komunikasi, (8) Citra dan Reputasi, (9) Kemudahan Tiket, dan (10) Kemudahan Pembayaran.

\section{Saran}

Perusahaan transporatasi laut yang menyediakan jasa penyeberangan untuk wisatawan dari Bali menuju Gili Trawangan agar lebih memperhatikan pelayanan atas jasa yang perusahaan berikan seperti pengorganisasian wisatawan yang sedang menunggu keberangkatan. Wisatawan merasa tidak diorganisasi dengan baik oleh perusahaan seperti dibiarkan menunggu untuk waktu yang tidak tentu dan informasi kapal yang mana yang akan ditumpangi oleh wisatawan tidak jelas.

Perusahaan transportasi laut yang menyediakan jasa penyeberangan untuk wisatawan dari Bali menuju Gili Trawangan harus memperhatikan biaya dan kemudahan untuk wisatawan yang menggunakan jasa dari masing-masing perusahaan terkait harga yang di dapatkan wisatawan. Hal ini berkaitan dengan bagaimana cara wisatawan mendapatkan tiket, semakin banyak pihak yang terlibat dalam penjualan tiket di masingmasing perusahaan, semakin mahal harga tiket yang di dapatkan oleh wistawan. Akan hal tersebut perusahaan seharusnya menetapkan tarif batas atas dan tarif batas bawah untuk tiket yang akan dibeli oleh wisatawan.

Perusahaan transportasi laut yang menyediakan jasa penyeberangan untuk wisatawan dari Bali menuju Gili Trawangan harus memperhatikan kualitas dari produk perusahaan terkait dengan tampilan kapal yang akan dinaiki oleh wisatawan. Sebagian wisatawan merasa kurang nyaman ketika melihat kapal yang akan dinaiki oleh wisatawan. Tidak semua perusahaan yang memiliki tampilan kapal yang kurang meyakinkan akan tetapi hal tersebut dapat menurunkan loyalitas wisatawan dikarenakan keyakinan wisatawan terhadap rasa aman ketika menaiki kapal beberapa perusahaan sangat rendah.

Pemerintah Nusa Tenggara Barat yang mengelola daerah tujuan wisata kepulaun Gili 
khususnya Gili Trawangan yang merupakan pintu masuk bagi wisatawan untuk berkunjung ke Kepulauan Gili, seharusnya menyediakan fasilitas tunggu yang memadai bagi wisatawan yang hendak berangkat dari Gili Trawangan menuju Bali. Pemerintah Nusa Tenggara Barat seharusnya memperhatikan wisatawan yang berkunjung ke Gili Trawangan seperti apa yang mereka inginkan dan mereka butuhkan, jika wisatawan yang berkunjung ke Gili Trawangan merasa lebih baik maka semua pihak yang berhubungan dengan wisatawan akan mendapatkan manfaat yang lebih baik.

Penelitian ini memiliki kelemahan terkait dengan sampel yang diambil dalam penelitian, maka untuk peneliti selanjutnya disarankan agar memilih perusahaan dengan harga yang relatif sama atau tidak jauh berbeda, dengan anggapan fasilitas dan kualitas yang disediakan oleh perusaahaan dalam penelitian ini sama. Karena kualitas dan fasilitas yang sama, maka mengukur kepuasan wisatawan pengguna transportasi laut dari Bali ke Gili Trawangan lebih jelas dan mudah untuk dibandingkan. 


\section{Kepustakaan}

Bitner, M. J. dan Zeithaml, V. A., 2003, Service Marketing (3rd ed.), Tata McGraw Hill, New Delhi.

Ghozali, Imam 2005, Aplikasi Analisis Multivariate Dengan Program SPSS, Badan Penerbit Universitas Diponogoro, Semarang.

Irawan, Juwandi, Hendy 2004, Kepuasan Pelayanan Jasa, Erlangga, Jakarta.

Kotler, Philip 2000, Manajemen Pemasaran. Jakarta: PT Prenhallindo. , Armstrong, Gary 1996. DasarDasar Pemasaran. Jakarta : Intermedia.

Lupiyoadi, Rambat 2001, Manajemen Pemasaran Jasa Teori dan Praktik. Jakarta: Salemba Empat.

Nasution, M.Nur 2004, Manajemen Jasa Terpadu. Jakarta: PT Ghalia Indonesia. 2008, Manajemen Transportasi edisi ketiga, Bogor: Ghalia Indonesia.

Paulalengan, 2016, 'Faktor - faktor yang mempengaruhi kepuasan wisatawan dalam penggunaan maskapai penerbangan Airasia di Denpasar', Jurnal IPTA, Vol. 4, No. 2, hh. 21.

Seaton, A.V., Bennett, M., M. 1996, Marketing Tourism Products, Oxford: Alden Press

Tjiptono, F 2003, Total Quality Management. Yogyakarta: Penerbit Andi offset.

Widarjono, Agus 2015, Analisis Multivariat Terapan. Yogyakarta: Penerbit UPP STIM YKPN

Yoeti, Oka, A. 1983. Pengantar ilmu pariwisata. Bandung: Angkasa. 